\title{
Opportunities and Challenges for Professionals in Psychiatry and Mental Health Care Using Digital Technologies During the COVID-19 Pandemic: Systematic Review
}

Hélène Kane ${ }^{1}$, PhD; Jade Gourret Baumgart ${ }^{1}$, MA; Wissam El-Hage ${ }^{2,3}$, Prof Dr; Jocelyn Deloyer ${ }^{4}$, MA; Christine Maes $^{4}$, BA; Marie-Clotilde Lebas ${ }^{5}$, MA; Donatella Marazziti ${ }^{6,7}$, MD; Johannes Thome ${ }^{8}$, MD, PhD; Laurence Fond-Harmant ${ }^{9,10}$, PhD, HDR; Frédéric Denis ${ }^{1}$, HDR

${ }^{1}$ Laboratoire Éducation, Éthique, Santé, Université de Tours, Tours, France

${ }^{2}$ Centre d'Investigation Clinique, Institut National de la Santé et de la Recherche Médicale, Tours, France

${ }^{3}$ Centre Hospitalier Régional Universitaire Tours, Tours, France

${ }^{4}$ Centre Neuropsychiatrique St-Martin, Namur, Belgium

${ }^{5}$ Département des Sciences de la Santé Publique et de la Motricité, Haute Ecole de la Province de Namur, Namur, Belgium

${ }^{6}$ Department of Experimental and Clinical Medicine, Section of Psychiatry, University of Pisa, Pisa, Italy

${ }^{7}$ Dipartimento di Medicina Clinica e Sperimentale, Section of Psychiatry, University of Pisa, Unicamillus-Saint Camillus International University of Health Sciences, Rome and Brain Research Foundation, Lucca, Italy

${ }^{8}$ Department of Psychiatry, University of Rostock, Rostock, Germany

${ }^{9}$ Agence de Coopération Scientifique Europe-Afrique-Luxembourg, Luxembourg, Luxembourg

${ }^{10}$ Education et Pratiques en Santé, Université Sorbonne Paris Nord, Paris, France

\section{Corresponding Author:}

Hélène Kane, $\mathrm{PhD}$

Laboratoire Éducation, Éthique, Santé

Université de Tours

Boulevard Tonnellé

Tours, 37032

France

Phone: 33279060019

Email: helene.kane@gmail.com

\section{Abstract}

Background: The COVID-19 pandemic has required psychiatric and mental health professionals to change their practices to reduce the risk of transmission of SARS-CoV-2, in particular by favoring remote monitoring and assessment via digital technologies.

Objective: As part of a research project that was cofunded by the French National Research Agency (ARN) and the Centre-Val de Loire Region, the aim of this systematic literature review was to investigate how such uses of digital technologies have been developing.

Methods: This systematic review was conducted following the PRISMA (Preferred Reporting Items for Systematic Reviews and Meta-Analyses) guidelines. The search was carried out in the MEDLINE (ie, PubMed) and Cairn databases, as well as in a platform specializing in mental health, Ascodocpsy. The search yielded 558 results for the year 2020. After applying inclusion and exclusion criteria, first on titles and abstracts and then on full texts, 61 articles were included.

Results: The analysis of the literature revealed a heterogeneous integration of digital technologies, not only depending on countries, contexts, and local regulations, but also depending on the modalities of care. Notwithstanding these variations, the use of videoconferencing has developed significantly, affecting working conditions and therapeutic relationships. For many psychiatric and mental health professionals, the pandemic has been an opportunity to build up their experience of remote care and, thus, better identify the possibilities and limits of these digital technologies.

Conclusions: New uses of such technologies essentially consist of a transition from the classic consultation model toward teleconsultation and make less use of the specific potential of artificial intelligence. As professionals were not prepared for these uses, they were confronted with practical difficulties and ethical questions, such as the place of digital technology in care, 
confidentiality and protection of personal data, and equity in access to care. The COVID-19 health crisis questions how the organization of health care integrates the possibilities offered by digital technology, in particular to promote the autonomy and empowerment of mental health service users.

(JMIR Hum Factors 2022;9(1):e30359) doi: 10.2196/30359

\section{KEYWORDS}

COVID-19; e-mental health; professional practices; quality of care; telepsychiatry; videoconferencing

\section{Introduction}

The spread of digital technology in health systems is a major and irreversible phenomenon, a source of changes that are only just beginning. Initiated several decades ago in the field of psychiatry and mental health care, the development of digital technologies has been increasing for several years [1-3]. Teleconsultation has notably begun to be used in specific contexts, such as when access to health care is at stake for expatriates or people living in isolated areas, while remaining marginal [4,5]. Technical difficulties, concerns about confidentiality, and regulatory barriers are among the obstacles to the development of telepsychiatry [6]. The expansion of new technologies offers more and more possibilities, including sensors that are able to collect clinical data related to physical activity, stress, or sleep. Intelligent applications are able to detect changes in individual behavior and then analyze this data to assist in screening and monitoring mental illnesses. Not only do such technologies open up new possibilities, but they might also bring about decisive changes to enhance the overall efficiency of mental health services [1,3].

The COVID-19 pandemic has highlighted the potential of these technologies, which have led to digital uses on an unprecedented scale in psychiatry. In particular, the pandemic revealed the contributions of these technologies to ensuring continuity of care while annihilating the risk of viral transmission in the context of an outbreak. As they allow remote monitoring of some patients, these technologies have been used in a wide range of strategies to reduce the risk of transmission of SARS-CoV-2. They have also made it possible to carry out interventions responding to needs that are specifically related to the epidemic, whether it be support for frontline health professionals or care for patients with COVID-19. The use of teleconsultation, previously in mental health care and psychiatry in its early stages, has massively increased in response to the health crisis and among measures that have been implemented to contain it $[7,8]$. These experiences of telepsychiatry, which started in emergency situations and were facilitated by exceptional arrangements and, often, regulatory relaxation [9], raise many questions about the evolution of health care and involve ethical and regulatory issues [10].

Mental health and psychiatric care specifically provide a central place to the therapeutic relationship. In this context, our attention is focused on the impact of digital technologies as a "relational artifact" (ie, the way they reconfigure care relationships).
The objectives of this study were (1) to describe the uses of digital technologies at the time of COVID-19 and their impact on professional practices in psychiatry and mental health and (2) to understand the place of digital technologies in the organizational adaptations linked to the COVID-19 epidemic, but also to identify how this specific context questions the modalities of care.

\section{Methods}

This systematic review was conducted according to the PRISMA (Preferred Reporting Items for Systematic Reviews and Meta-Analyses) guidelines [11].

\section{Search Strategy}

A systematic literature search was carried out in two databases, MEDLINE (ie, PubMed) and Cairn, and a specialized mental health platform, Ascodocpsy; all included articles met the inclusion criteria. Search terms were defined by articulating keywords, which were previously defined from dictionaries of synonyms and thesauri alone or in combination with the Boolean operators "AND" and "OR" (Table 1). The search, which was carried out on titles and abstracts, only concerned the year 2020, with extraction of results taking place as of December 31, 2020. Our process did not generate any results in previous years, which is consistent with the date that the COVID-19 epidemic began. Only peer-reviewed articles accepted for publication and available in English or French were included. Editorials were excluded.

After a preliminary exploratory search, all authors agreed on the inclusion and exclusion criteria. To be included in the literature review, articles had to meet the following criteria: deal with the use of digital technologies as a response to the pandemic context and be related to the field of mental health care or psychiatry. On the other hand, the following were excluded: articles documenting the impacts of COVID-19 on mental health and psychiatry in general, adaptations of the health care offering carried out independently of the digital possibilities, and uses of digital tools in mental health and psychiatry independent of the COVID-19 outbreak.

In order to benefit from international experiences in an unprecedented context where many countries were simultaneously confronted with the same challenges, we chose not to exclude references based on geographical criteria. 
Table 1. Search terms used to find articles for this review.

\begin{tabular}{|c|c|c|}
\hline Database & Thesaurus & Search terms \\
\hline $\begin{array}{l}\text { PubMed } \\
\text { (MEDLINE) }\end{array}$ & Yes & $\begin{array}{l}\text { ("coronavirus" OR "covid-19" OR "sars-cov-2") AND ("mental health worker" OR "psychiatry" } \\
\text { OR "mental health professional" OR "psychiatrist" OR "psychologist" OR "psychiatric nurse" } \\
\text { OR "e-professional in psychiatry" OR "e-mental health") }\end{array}$ \\
\hline Cairn & No & $\begin{array}{l}\text { (“covid-19” OU “sars-cov-2” OU “coronavirus”) ET ("psychiatrie” OU "santé mentale” OU } \\
\text { "psychologue” OU “infirmier en psychiatrie” OU "pair-aidant” OU "médiateur de santé pair" } \\
\text { OU "e-professionnel de la psychiatrie") }\end{array}$ \\
\hline Base SantéPsy (Ascodocpsy) & Yes & $\begin{array}{l}\text { Base set contains "covid-19" ET ("psychiatrie" OU "santé mentale" OU "psychologie" OU } \\
\text { "hôpital psychiatrique") }\end{array}$ \\
\hline
\end{tabular}

\section{Study Detection}

The search yielded a total of 558 documents, 39 of which were duplicates that were excluded. The first two authors (HK and JGB) preselected references by applying the inclusion and exclusion criteria on abstracts and agreed to select 91 articles. A careful reading of the documents resulted in the exclusion, after consultation, of 30 more articles. Therefore, a total of 61 references were selected (Figure 1).

Figure 1. Flowchart of article selection for this review.
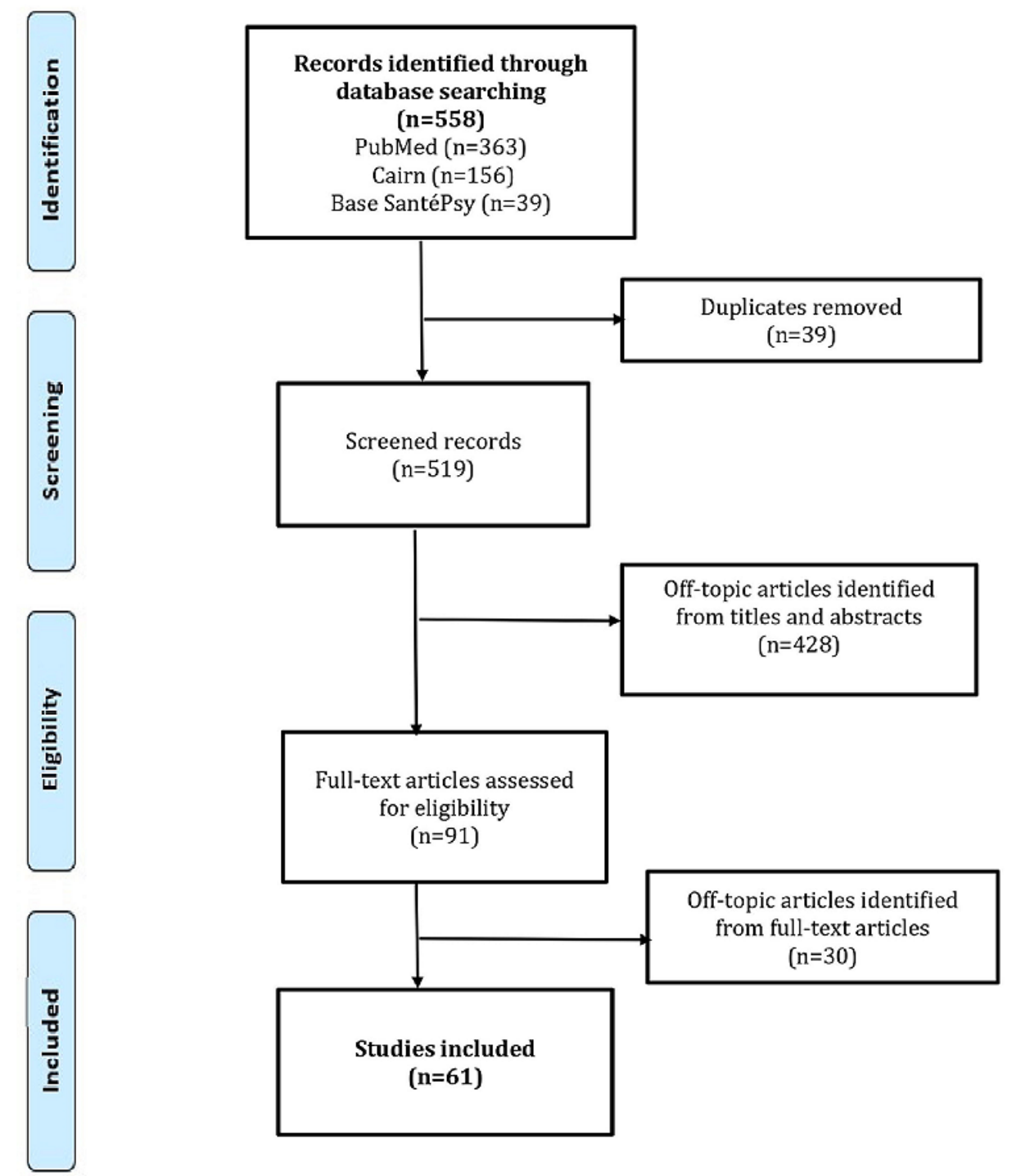


\section{Results}

\section{Contributions From the Use of Digital Technologies in Mental Health Care and Psychiatry}

This literature review shows that, in the context of the current crisis and as professional practices need to adapt, publications have been produced at a rapid rate. The use of digital technologies appeared to be a crucial issue, which was addressed in 61 articles in the year 2020 alone. Table 2 [5,7,12-70] describes the characteristics of these articles, the digital technologies they addressed, their main uses, and the fields of application mentioned.

The methodological quality of these contributions turned out to be quite poor, due to a lack of time and hindsight to carry out more rigorous work. About half of them (30/61, 49\%) were feedback articles. They show the willingness of those involved in psychiatry and mental health care to share their experiences and innovations in the midst of the COVID-19 crisis. Such publications reflect an acceleration in the exchange of professional practices on an international scale. They used diverse methodologies, ranging from personal narratives to more collaborative and structured forms of feedback and analysis of experience. The presence of $8(13 \%)$ reflection-based articles also shows the willingness of professionals to share their concerns. Another set of $14(23 \%)$ articles were literature reviews, either narrative or systematic. In the end, of the 61 articles, only $9(15 \%)$ were original research studies.

Selected articles included many countries, spread over five continents, which were simultaneously confronted with similar issues related to the use of digital technologies in response to the pandemic. The largest number of articles concerned Western and Northern Europe $(n=24,39 \%)$ and North America $(n=23$, $38 \%)$. 
Table 2. Characteristics and themes of the selected articles.

\begin{tabular}{|c|c|c|}
\hline Characteristics & Studies $(\mathrm{N}=61), \mathrm{n}(\%)$ & References \\
\hline \multicolumn{3}{|l|}{ Type of article } \\
\hline Experience feedback & $30(49)$ & [12-41] \\
\hline Literature review & $14(23)$ & {$[5,7,42-53]$} \\
\hline Study & $9(15)$ & [54-62] \\
\hline Reflection & $8(13)$ & [63-70] \\
\hline \multicolumn{3}{|l|}{ Location of study } \\
\hline Europe & $24(39)$ & {$[5,13,14,18,19,26,27,29,31,33,36,38,40,42,44,50,54,57,58,60-62,64,65]$} \\
\hline North America & $23(38)$ & {$[7,12,15,17,20-24,30,32,34,35,37,39,41,45,46,48,49,52,63,66]$} \\
\hline Asia & $8(13)$ & {$[16,47,51,53,55,67,68,70]$} \\
\hline Australia & $4(7)$ & {$[25,43,59,69]$} \\
\hline Africa & $2(3)$ & {$[28,56]$} \\
\hline \multicolumn{3}{|l|}{ Digital tool } \\
\hline Videoconferencing & $45(74)$ & {$[22,24,26-35,37,39-41,47,50,52,58,59,61,66,68-70]$} \\
\hline Telephone & $27(44)$ & {$[24-27,32,33,35-37,39,51,59,60,62,68,69]$} \\
\hline App & $10(16)$ & {$[29,47-49,51,53-55,64,67]$} \\
\hline Connected device & $5(8)$ & {$[47-49,65,67]$} \\
\hline Website & $4(7)$ & {$[30,53,56,68]$} \\
\hline Artificial intelligence & $4(7)$ & {$[48,49,64,67]$} \\
\hline \multicolumn{3}{|l|}{ Use of digital tools } \\
\hline Patients' follow-up and care & $44(72)$ & {$[5,7,12-21,23,25-29,31-38,41-43,46,48-50,52,57,58,60,61,63,65-68,70]$} \\
\hline Public support for COVID-19 & $9(15)$ & {$[35,44,49,51,53,54,56,62,64]$} \\
\hline Group therapy & $8(13)$ & {$[17,19,21,30,34,39,50,67]$} \\
\hline Assessment and diagnosis & $7(11)$ & {$[22,25,45,49,60,62,65]$} \\
\hline Support for health professionals & $5(8)$ & {$[30,39,44,55,62]$} \\
\hline Care of patients with COVID-19 & $5(8)$ & {$[14,16,17,40,53]$} \\
\hline Staff meeting & $5(8)$ & {$[7,16,27,34,41]$} \\
\hline \multicolumn{3}{|l|}{ Domain } \\
\hline Psychiatry in general & $29(48)$ & {$[5,7,14,15,17,20,21,24,25,28,34,40-44,46,50,52,55,57-60,63,66-69]$} \\
\hline Psychology & $14(23)$ & {$[16,24,30,33,35,36,39,40,47,49,53,54,62,64]$} \\
\hline Mental health promotion & $8(13)$ & {$[44,47,49,51,53,56,62,64]$} \\
\hline Child psychiatry & $5(8)$ & {$[13,18,29,32,37]$} \\
\hline Geriatric psychiatry & $5(8)$ & {$[31,38,56,61,65]$} \\
\hline Community health & $4(7)$ & {$[12,23,27,68]$} \\
\hline Forensic psychiatry & $3(5)$ & {$[22,26,45]$} \\
\hline Addiction & $3(5)$ & {$[19,48,70]$} \\
\hline
\end{tabular}

\section{Adopting New Digital Technologies}

Most of the articles selected for this literature review (45/61, $74 \%$ ) mentioned the use of videoconferencing. This technology has been used, in particular, in interventions with mental health and psychiatric professionals who provide care for patients with COVID-19 [30,39,55] or, more broadly, for the population affected by the COVID-19 pandemic [40,51,62].

Videoconferencing consultations and group discussions took place alongside on-site interventions and telephone helplines.

However, teleconsultation has been massively developed to ensure continuity of care. Videoconferencing has made it possible to maintain not only remote monitoring of patients, but also therapy groups $[17,48]$ and meetings between professionals. This particular use of this technology at an unprecedented scale has been developed at the intersection of 
two phenomena: the constraint of physical distancing measures aimed at containing the epidemic and the achievement of a high level of digital performance that allows for seamless use of videoconferencing. This rapid expansion of teleconsultation is perhaps the most important impact of the pandemic on the organization of care in psychiatry [7]. This sudden evolution has often gone along with the use of videoconferencing platforms, such as Skype, Zoom, or Microsoft Teams, despite their use raising security and confidentiality issues $[17,20,21,32,41,43]$. Specialized digital health platforms, such as MyChart by Epic, have been less frequently employed. In some cases, the use of videoconferencing has been combined with that of more familiar telecommunication tools, such as the telephone [17,36,38,57,59], emails, or SMS [34]. In our literature review, the telephone was the second most frequently mentioned digital technology, with 27 out of 61 (44\%) references cited.

In most psychiatric services, however, this switch to remote communication is not yet complete, forcing practitioners to determine which activities require face-to-face meetings and which ones can be done via videoconferencing [14,16,23,25]. In particular, in-person examination has been maintained for patients who are deemed vulnerable and at risk [25].

As the number of remote consultations increased, prescription procedures have also been impacted. In order to limit the number of in-person appointments, practitioners have either used tele-prescription or opted for prescriptions covering a longer period. For treatments that require follow-up of specific clinical parameters, such as Clozapine, which involves monitoring blood counts, protocols have been made more flexible, sometimes allowing for a remote assessment of the clinical condition of patients $[23,29,71]$.

In addition, 10 articles (16\%) discussed connected apps and devices. In particular, their authors highlighted the relevance of connected apps and devices to assist remote monitoring during the pandemic $[48,54,64]$. Although the analyzed literature mentioned the potential of these new technologies, none of the identified publications documented the possible increase in their use in the context of a health crisis. Only 2 (3\%) references were about apps that enabled the connection between patients and health professionals $[51,55]$.

\section{Heterogeneous Integration of Digital Technologies}

Although the COVID-19 pandemic has stimulated the development of telepsychiatry on all continents, our review of the literature allowed us to glimpse variations between countries. In the United States, due to the removal of regulatory barriers, the shift to telepsychiatry has been massive and even total in certain units, as illustrated by numerous publications $[15,24,32,34,37,41]$. In many European countries, telepsychiatry has gone from a niche practice to an essential modality for providing mental health services; this has been so in Germany [27], Spain [62], France [13,18,42], Ireland [19,29,50], the Netherlands [57], and Switzerland [65]. Telemedicine was adopted, even in countries such as North Macedonia, where public policies had previously been rather opposed to it [58]. A similar situation was reported in Australia [25,43,69]. In some cases, barriers persist, as in Canada, where the lack of health insurance coverage for teleconsultation with mental health professionals prevented its expansion during the pandemic [35]. Other countries, such as India, have been quick to innovate in favor of integrating digital technologies $[47,68]$, and they rely on the development of telepsychiatry in order to increase health care delivery, despite limited resources. Developing telemedicine has been more difficult in some countries of the Global South due to a lower spread of information and communication technology [28,51]. Although advancing heterogeneously, the COVID-19 pandemic has been stimulating the integration of digital technologies into health care, confronting many countries simultaneously with comparable problems.

Within countries, these trends raise the issue of unequal access to digital technologies. Consequently, the development of telepsychiatry may disadvantage people living in poverty $[23,63]$ and older adults who do not have access to these technologies $[31,38,56]$.

Moreover, many authors have reassessed the appropriateness of telepsychiatry depending on the patients and their disorders, which had already been documented in the literature [3]. Telepsychiatry seems inappropriate for use with children whose attention is difficult to capture from a distance [29,69], as well as with older patients, who are less familiar with digital technologies and frequently suffer from hearing and visual impairments $[38,60,61]$. On the other hand, telepsychiatry is likely to facilitate access to health care for youth who are accustomed to new technologies [32].

Specific problems with the use of these technologies have arisen in certain fields, such as forensic psychiatry [45,72], the treatment of drug addiction [70], or electrostimulation techniques [7]. Although facilitating some procedures [22], remote forensic assessments are at risk of being disqualified for "procedural defects" [45]. On the other hand, the possibility of appearing in court by videoconference has prevented some forms of stress for people with mental disorders [26]. With regard to the treatment of drug addiction, specific difficulties may be related to legislative measures taken to prevent the diversion and misuse of certain drugs, by prohibiting tele-prescription, among other restrictions [70].

These numerous contributions found in the scientific literature, which were based on new experiments in the context of the COVID-19 pandemic, have added to the established knowledge about the relevance of telepsychiatry in different situations.

\section{Experiencing New Conditions of Professional Practice}

The use of telepsychiatry, which makes it possible to reduce the risks of infection, has generated new conditions of practice for many professionals, defining both new possibilities and constraints. For independent practitioners, teleconsultation is no longer necessarily a freely chosen practice [4], but a means of maintaining their practice despite the restrictions imposed by public health measures. In hospital services, the decision to switch some services to a remote mode has been taken by those in charge in a more or less constrained way, or more or less consensually. Many professionals have had to adapt their 
practices, even though they were initially hostile to the use of digital technologies [5,42].

It should be noted that this new digital work experience has sometimes been associated with teleworking from home [27,33], in a general context of lack of preparation. Most of the professionals concerned were not trained in telepsychiatry follow-up, and some were not very comfortable with new technologies [33]. At the same time, they had to learn how to use digital technologies to support their patients, manage their own stress, and sometimes set up home-based work processes $[15,52]$. The accumulation of all these tensions can lead to emotional exhaustion [52].

Professionals teleworking from home have been confronted with unprecedented situations of temporal and spatial juxtaposition of both their professional and personal lives. This juxtaposition requires "psychological work to differentiate between private and professional lives that is more costly than usual" [33]. However, other authors mention that telework can also facilitate work-life balance in psychiatry [41,60], and practitioners reported that caring for a patient while teleworking nevertheless had a positive impact on their well-being in the midst of the crisis [41].

Moreover, the use of digital technologies, especially as their use is improvised and unframed, is likely to lead to an increased workload. Professionals may be exposed to an accumulation of requests through multiple technologies: videoconferencing, telephone, email, and SMS [15]. For them, the extensive use of videoconferencing can be a source of fatigue [24,52], described as "Zoom fatigue" [34], and a source of stress [34,52]. This fatigue is related to efforts to communicate and establish a relationship via videoconferencing [15], to the difficulty of sticking to a schedule with time slots that are explicitly dedicated to each patient, and to all the operations required to disconnect and reconnect to each device [34]. And yet, after overcoming technical and organizational obstacles, professionals can take advantage of those digital technologies, which can also bring more flexibility and help them save time [57], as documented in research prior to the pandemic [73].

Having experiences of care relationships reshaped by digital technologies in the context of this pandemic, psychiatric and mental health professionals have been using videoconferencing and the telephone to follow up on many patients. For health care providers, the COVID-19 crisis has been an opportunity to build up their experience of remote health care monitoring and, thus, better understand the possibilities and limitations of such digital technologies. This unprecedented context forced them to reinvent "relational mental health" [42]. Among other consequences, telepsychiatry favors more fragmented care modalities, with shorter and more frequent encounters [15,57].

Furthermore, although the effectiveness of telepsychiatry had already been documented [3,50,74], many professionals were skeptical about the possibility of establishing, maintaining, and strengthening a therapeutic relationship [66]. They feared that they would lose not only human contact, but also control over their image [3]. Some feared that the screen would become a barrier to the therapeutic process [29]. After experiencing telepsychiatry in the context of the health crisis, assessments remain contrasted [20]. Some authors mentioned that teleconsultation tends to hinder verbal and nonverbal communication [20,30,34,48,53]. In addition to the difficulty in grasping nonverbal body language [20,34,53], it is no longer possible to smell odors [46,53], see how patients are dressed, and perceive certain attitudes [46]. Communication must do without physical contact, such as greeting each other with a handshake [29], and empathy can no longer be manifested by comforting gestures [61]. Videoconferencing introduces a new mode of presence to the other, sometimes inducing a feeling of dissonance due to audiovisual presence and bodily absence [20]. The feeling of intimacy and confidence is not the same as in a closed office, and consultation no longer benefits from a separate space and time but is embedded in everyday life [30].

The professionals were also led to discover the advantages of digital technologies. The use of videoconferencing can be an opportunity to better contextualize some information, since part of the patient's environment is made visible [16,53]. Teleconsultation can also make it possible to remove certain inhibitions and to access the unconscious more easily [9]. A few authors identified advantages of telephone consultations over videoconferences, especially for short talks [55]. In some cases, conducting telephone consultations allowed patients greater freedom of expression and allowed professionals to listen more carefully [14].

Although telepsychiatry allows for a large number of follow-up consultations, several authors mentioned that the greatest difficulty was in establishing a therapeutic relationship without a prior face-to-face encounter [46]. As a result, in the context of COVID-19, psychiatric and mental health professionals tended to postpone work on trauma, focusing instead on maintaining the patient's well-being and encouraging activities to achieve this goal [34]. With regard to diagnosis, almost all professionals interviewed in a study that was conducted in Ireland reported that they were less comfortable making a diagnosis based on a telephone consultation [56]. Similarly, conducting neuropsychological assessments from a distance presents specific difficulties [14,61].

Although already documented, the possibilities and limits of telepsychiatry were highlighted by the COVID-19 epidemic, illustrating how experience can help to gradually shape new therapeutic practices integrating digital technologies.

\section{Discussion}

\section{Principal Findings}

The profusion of articles identified in the framework of this literature review shows how much the COVID-19 crisis has raised issues about care practices in psychiatry and how they integrate the available digital technologies. Such integration proves to be heterogeneous, depending on local contexts and regulations, but also regarding the fields and modalities of care. The use of videoconferencing has had an impact not only on the working conditions of mental health and psychiatric professionals, but also on the care relationships they maintain with their patients. This sudden shift to remote care has prompted professionals to publish papers about their experiences 
with telepsychiatry, sometimes in a naive way, without building on pre-existing research.

\section{Lack of Preparation Confronting Professionals With Ethical Questions}

The experience of videoconferencing, in a context where mental health and psychiatric professionals had not been prepared for it, calls into question the quality of care [60]. Many professionals have used teleconsultation without training or knowledge of existing protocols and recommendations [75]. This lack of preparation pushed them to improvise and confronted them with ethical dilemmas. This unprecedented situation raises questions about privacy and the protection of personal data [47] as well as the risk of increasing inequalities in access to health care $[48,50,63]$. Indeed, the rapid expansion of telemedicine hinders access to health care for patients who do not possess, nor are proficient in, the necessary technology [9].

To guarantee the best conditions for confidentiality, special attention should be paid to the choice of digital technologies to be used. In the context of the current crisis, this choice has been little considered and is essentially based on pragmatic considerations. The use of new technologies requires special precautions, such as using headphones, consulting in a closed room, and disconnecting when absent [20]. Therefore, their use requires awareness and support from professionals in order to ensure the protection of personal data [47]. In addition, remote intervention involves knowing where the patient is and what local resources are available to respond to emergency situations [75].

The partial or total shift to remote consultations also raises the issue of equity in the provision of health care. Many professionals have been forced to identify vulnerable patients who require face-to-face encounters and those who can be monitored remotely $[14,15,23,25]$. This process of triage and separation between patients has confronted them with ethical dilemmas, particularly in the case of patients who are at risk of both a relapse of their mental illness and developing severe forms of COVID-19. Guidelines were sometimes developed to help identify patients for whom a face-to-face appointment was absolutely necessary [12]. Some authors warned against excluding vulnerable people or people living in poverty who do not have access to the internet or are limited by low digital literacy $[63,68]$. The situation of older adult patients, who are often unfamiliar with new technologies, also requires special attention. Not supporting them in the use of these tools constitutes a form of ageism [31]. Not only are older people not always averse to new technologies, but the issue of distance is all the more important as they are vulnerable to COVID-19 [65]. The experience of these new uses of digital technology opens the way to forms of differentiated care that make it possible to adapt care delivery to patients' preferences, in order to improve the overall quality of care.

\section{Uses That Do Not Exploit the Full Potential of Digital Technology}

In showing many professionals the potential of digital technologies, the COVID-19 crisis also revealed the extent to which their nonuse can be an ethical challenge. Digital technologies can reduce regional inequalities in access to health care [52] and can prevent significant costs and travel time $[18,68]$. Moreover, many patients have expressed their satisfaction with their experience of telepsychiatry $[19,32,46,58]$, which confirms previous data from the literature [3]. Although some patients feel less supported in teleconsultations, others appreciate the freedom to access health care from an online platform [19]. Telepsychiatry can also foster patient autonomy $[19,50,76]$ and the development of a form of empowerment that health organizations have been advocating for [77]. For example, it allows patients to record consultations in order to fully assimilate the information, thus increasing their power to act on the care relationship [50]. The experience of videoconferencing has allowed some professionals to overcome part of their initial reluctance [6] and to realize how valuable the virtual space of teleconsultation can be for building certain forms of intimacy in the therapeutic relationship [76,78]. However, in emergency and unpreparedness contexts, the experience of telepsychiatry did not take place in optimal conditions for their appropriation. In particular, some professionals experimented with videoconferencing when they were teleworking and not in their offices. The COVID-19 crisis has, nevertheless, made visible the extent to which digital technology can be a driving force for change in psychiatry [26]. It paves the way for the development of a hybrid care system integrating the strengths of teleconsultations as a complement to face-to-face encounters $[3,8,76]$.

However, while the use of teleconsultation has been significant, professional uses of apps and connected devices do not seem to have been as stimulated by the health crisis. According to some authors, the pandemic, nevertheless, made it urgent to use such tools in order to intervene on a large scale to relieve the mental health burden induced by the crisis [54,67,79]. By providing clinical information, dedicated apps can also help to develop more personalized care plans [67]. The possibilities offered by digital phenotyping open up new perspectives for remote monitoring and assessment, making it possible, in particular, to detect the occurrence of disorders or relapses $[48,49]$. Even in a crisis context, the use of these tools has been hampered by the lack of both evaluations proving their effectiveness [54,64,79] and appropriate regulations [64]. Although the use of digital technologies has been stimulated by the crisis, in health care systems, it has essentially consisted of a transfer from in-person consultation to teleconsultation. In the end, health care has not taken full advantage of the specific intervention potential of digital technologies and artificial intelligence.

\section{Challenges to Better Integration of Digital Technologies in the Organization of Health Care}

The COVID-19 health crisis questions the organization of care and the way it integrates new possibilities offered by digital technology. The scientific publications that we have identified mainly addressed the issues related to teleconsultation, sometimes ignoring previous research. The impact of the use of digital technology on relationships between professionals is poorly documented. However, the use of digital technologies is reshaping the conditions of teamwork and allows for new modalities of interprofessional collaboration [80,81]. The stakes 
are high, since digital technologies open up the possibility of numerous contacts between professionals working in different places. In particular, they make possible new collaborations between mental health and somatic professionals, and they allow a reorganization of consultation-liaison psychiatry. Constraints also need to be examined, since videoconference work meetings reduce interactional diversity, especially informal interactions. Such development is likely to affect well-being at work and social support between professionals in the context of crisis. However, other research has shown that telepsychiatry can allow professionals to optimize their working time and reduce their risk of burnout [73]. Remote team management, however, requires specific approaches [80].

Digital technologies also question the place of users and their relatives in the organization of care. As a result of the increase in outpatient and remote follow-up during lockdown periods, many patients have become more autonomous in managing their mental health [50]. Telepsychiatry can support the development of integrated patient-centered care, allowing for a more precise match between health care providers' skills and patients' needs [81]. Families have also been placed in the front line, pushed to take on new responsibilities $[18,68]$. Because community health services limited their travel, families relied more heavily on community resources [23]. New possibilities offered by digital technology thus invite new research to be conducted into community-based approaches to mental health.

\section{Conclusions}

The COVID-19 pandemic has led to new uses of telepsychiatry, with the aim of ensuring continuity of care while limiting the risk of transmission of SARS-CoV-2. Such expansion was essentially characterized by the integration of videoconferencing as a new framework for consultation. Many mental health and psychiatric professionals started experiencing remote health care monitoring and assessment in a hurry and with no preparation. They have become familiar with the constraints, possibilities, and assets of care relationships in this type of context. These new conditions of professional practice have confronted them with ethical questions, such as equity in access to care. Existing research resources and data could be mobilized to enable these professionals to better leverage the benefits of digital technologies to complement face-to-face meetings. Further interdisciplinary work will be needed to better understand variations in digital technology uses across countries.

The use of digital technologies during the COVID-19 epidemic have shed light on the organization of mental health and psychiatric care, and about the place of users within this context of care. In a context where hospitals and health centers are no longer the only spaces where care and support are delivered, access to care and "decoding" the eHealth world constitute a pillar of tomorrow's public health [71].

\section{Acknowledgments}

We thank the French National Research Agency (ARN) and the Centre-Val de Loire Region for funding our research.

\section{Conflicts of Interest}

WEH received speaker fees from Air Liquide, Eisai, Janssen, Lundbeck, Otsuka, UCB Pharma, and Chugai. WEH has received research grants from the Fondation de France and from the French National Hospital Program for Clinical Research (PHRC) that are unrelated to the submitted work.

\section{References}

1. Briffault X. Psychiatrie 3.0: Etre Soi et ses Connexions. Paris, France: Doin; 2019:1-223.

2. Shore J. The evolution and history of telepsychiatry and its impact on psychiatric care: Current implications for psychiatrists and psychiatric organizations. Int Rev Psychiatry 2015;27(6):469-475. [doi: 10.3109/09540261.2015.1072086] [Medline: 26397182]

3. Chakrabarti S. Usefulness of telepsychiatry: A critical evaluation of videoconferencing-based approaches. World J Psychiatry 2015 Sep 22;5(3):286-304 [FREE Full text] [doi: 10.5498/wjp.v5.i3.286] [Medline: 26425443]

4. Mathieu-Fritz A. Les téléconsultations en santé mentale. Ou comment établir la relation psychothérapeutique à distance. Réseaux 2018;207(1):123-126. [doi: 10.3917/res.207.0123]

5. Advenier F, Reca M. Téléconsultations pendant le confinement en cabinet de ville. Inf Psychiatr 2020;96(8):601-607 [FREE Full text]

6. Chan S, Parish M, Yellowlees P. Telepsychiatry today. Curr Psychiatry Rep 2015 Nov;17(11):89. [doi: 10.1007/s11920-015-0630-9] [Medline: 26384338]

7. Cabrera MA, Karamsetty L, Simpson SA. Coronavirus and its implications for psychiatry: A rapid review of the early literature. Psychosomatics 2020;61(6):607-615 [FREE Full text] [doi: 10.1016/j.psym.2020.05.018] [Medline: 32943211]

8. Mishkind M, Shore J, Schneck C. Telemental health response to the COVID-19 pandemic: Virtualization of outpatient care now as a pathway to the future. Telemed J E Health $2021 \mathrm{Jul}$;27(7):709-711. [doi: 10.1089/tmj.2020.0303] [Medline: 33297849]

9. Kinoshita S, Cortright K, Crawford A, Mizuno Y, Yoshida K, Hilty D, et al. Changes in telepsychiatry regulations during the COVID-19 pandemic: 17 countries and regions' approaches to an evolving healthcare landscape. Psychol Med 2020

Nov 27:1-8. [doi: 10.1017/s0033291720004584] 
10. CCNE. Numérique et Santé: Quels Enjeux Éthiques Pour Quelles Régulations?. Paris, France: CCNE; 2018 Nov 19. URL: https://www.ccne-ethique.fr/sites/default/files/publications/rapport numerique et sante 19112018.pdf [accessed 2022-01-26]

11. Moher D, Liberati A, Tetzlaff J, Altman DG, PRISMA Group. Preferred Reporting Items for Systematic Reviews and Meta-Analyses: The PRISMA statement. PLoS Med 2009 Jul 21;6(7):e1000097 [FREE Full text] [doi:

10.1371/journal.pmed.1000097] [Medline: 19621072]

12. Alavi Z, Haque R, Felzer-Kim IT, Lewicki T, Haque A, Mormann M. Implementing COVID-19 mitigation in the community mental health setting: March 2020 and lessons learned. Community Ment Health J 2021 Jan;57(1):57-63 [FREE Full text] [doi: 10.1007/s10597-020-00677-6] [Medline: $\underline{\text { 32681409] }}$

13. Alibert JF. Les psychothérapies d'enfant en visio pendant le confinement: Pour le meilleur et pour le pire... Retour d'expérience. Inf Psychiatr 2020;96(8-9):617-622. [doi: 10.1684/ipe.2020.2161]

14. Barry H, Doherty AM, Clancy M, Moore S, MacHale S. Lockdown logistics in consultation-liaison psychiatry. Ir J Psychol Med 2020 Sep 11:1-9 [FREE Full text] [doi: 10.1017/ipm.2020.104] [Medline: 32912345]

15. Chen JA, Chung W, Young SK, Tuttle MC, Collins MB, Darghouth SL, et al. COVID-19 and telepsychiatry: Early outpatient experiences and implications for the future. Gen Hosp Psychiatry 2020;66:89-95 [FREE Full text] [doi: 10.1016/j.genhosppsych.2020.07.002] [Medline: 32750604]

16. Cheng W, Zhang F, Hua Y, Yang Z, Liu J. Development of a psychological first-aid model in inpatients with COVID-19 in Wuhan, China. Gen Psychiatr 2020;33(3):e100292 [FREE Full text] [doi: 10.1136/gpsych-2020-100292] [Medline: 32596642]

17. Childs AW, Unger A, Li L. Rapid design and deployment of intensive outpatient, group-based psychiatric care using telehealth during coronavirus disease 2019 (COVID-19). J Am Med Inform Assoc 2020 Jul 01;27(9):1420-1424 [FREE Full text] [doi: 10.1093/jamia/ocaa138] [Medline: 32687151]

18. Chokron S. Apport de la téléconsultation au bilan neuropsychologique de l'enfant. Rev Neuropsychol 2020;12(2):152-154. [doi: 10.1684/nrp.2020.0556]

19. Columb D, Hussain R, O'Gara C. Addiction psychiatry and COVID-19: Impact on patients and service provision. Ir J Psychol Med 2020 Sep;37(3):164-168 [FREE Full text] [doi: 10.1017/ipm.2020.47] [Medline: 32434597]

20. Cowan A, Johnson R, Close H. Telepsychiatry in psychotherapy practice. Innov Clin Neurosci 2020 Apr 01;17(4-6):23-26 [FREE Full text] [Medline: 32802589]

21. Datta N, Derenne J, Sanders M, Lock JD. Telehealth transition in a comprehensive care unit for eating disorders: Challenges and long-term benefits. Int J Eat Disord 2020 Nov;53(11):1774-1779. [doi: 10.1002/eat.23348] [Medline: 32715512]

22. Green AS, Ruchman SG, Katz CL, Singer EK. Piloting forensic tele-mental health evaluations of asylum seekers. Psychiatry Res 2020 Sep;291:113256 [FREE Full text] [doi: 10.1016/j.psychres.2020.113256] [Medline: $\underline{32619825]}$

23. Guan I, Kirwan N, Beder M, Levy M, Law S. Adaptations and innovations to minimize service disruption for patients with severe mental illness during COVID-19: Perspectives and reflections from an assertive community psychiatry program. Community Ment Health J 2021 Jan;57(1):10-17 [FREE Full text] [doi: 10.1007/s10597-020-00710-8] [Medline: 32930903]

24. Ingram DH, Best K. The psychodynamic psychiatrist and psychiatric care in the era of COVID-19. Psychodyn Psychiatry 2020;48(3):234-258. [doi: 10.1521/pdps.2020.48.3.234] [Medline: $\underline{32996853}$ ]

25. Kavoor A, Chakravarthy K, John T. Remote consultations in the era of COVID-19 pandemic: Preliminary experience in a regional Australian public acute mental health care setting. Asian J Psychiatr 2020 Jun;51:102074 [FREE Full text] [doi: 10.1016/j.ajp.2020.102074] [Medline: 32294583]

26. Kennedy H, Mohan D, Davoren M. Forensic psychiatry and Covid-19: Accelerating transformation in forensic psychiatry. Ir J Psychol Med 2021 Jun;38(2):145-153 [FREE Full text] [doi: 10.1017/ipm.2020.58] [Medline: 32434610]

27. Lyne J, Roche E, Kamali M, Feeney L. COVID-19 from the perspective of urban and rural general adult mental health services. Ir J Psychol Med 2020 Sep;37(3):181-186 [FREE Full text] [doi: 10.1017/ipm.2020.62] [Medline: 32434599]

28. Marehin M, Mboumba Hinnouo A, Obiang P. Organisation of psychiatric care in Gabon during the COVID-19 epidemic [Article in French]. Ann Med Psychol (Paris) 2021 Feb;179(2):137-140 [FREE Full text] [doi: 10.1016/j.amp.2020.08.015] [Medline: 32863389]

29. McGrath J. ADHD and Covid-19: Current roadblocks and future opportunities. Ir J Psychol Med 2020 Sep;37(3):204-211 [FREE Full text] [doi: 10.1017/ipm.2020.53] [Medline: 32434606]

30. Mellins C, Mayer L, Glasofer D, Devlin M, Albano A, Nash S, et al. Supporting the well-being of health care providers during the COVID-19 pandemic: The CopeColumbia response. Gen Hosp Psychiatry 2020;67:62-69 [FREE Full text] [doi: 10.1016/j.genhosppsych.2020.08.013] [Medline: 33059217]

31. Naarding P, Oude Voshaar RC, Marijnissen R. COVID-19: Clinical challenges in Dutch geriatric psychiatry. Am J Geriatr Psychiatry 2020 Aug;28(8):839-843 [FREE Full text] [doi: 10.1016/j.jagp.2020.05.019] [Medline: 32565007]

32. Ramtekkar U, Bridge JA, Thomas G, Butter E, Reese J, Logan E, et al. Pediatric telebehavioral health: A transformational shift in care delivery in the era of COVID-19. JMIR Ment Health 2020 Sep 18;7(9):e20157 [FREE Full text] [doi: 10.2196/20157] [Medline: $\underline{32525485]}$

33. Robin-Poupard F. Distanciation sociale, masques et visioconférence: Être thérapeute au temps de la Covid-19. J Psychol 2020;382(10):70-74. [doi: 10.3917/jdp.382.0070] 
34. Sasangohar F, Bradshaw MR, Carlson MM, Flack JN, Fowler JC, Freeland D, et al. Adapting an outpatient psychiatric clinic to telehealth during the COVID-19 pandemic: A practice perspective. J Med Internet Res 2020 Oct 01;22(10):e22523 [FREE Full text] [doi: $\underline{10.2196 / 22523}$ ] [Medline: $\underline{\text { 32936768] }}$

35. Scharf D, Oinonen K. Ontario's response to COVID-19 shows that mental health providers must be integrated into provincial public health insurance systems. Can J Public Health 2020 Aug;111(4):473-476 [FREE Full text] [doi: 10.17269/s41997-020-00397-0] [Medline: 32767269]

36. Scheider F. Le soutien téléphonique des patients isolés souffrant de troubles psychiques: Trame pour l'approche clinique en réhabilitation. Inf Psychiatr 2020:239-242. [doi: 10.1684/ipe.2020.2093]

37. Sharma A, Sasser T, Schoenfelder Gonzalez E, Vander Stoep A, Myers K. Implementation of home-based telemental health in a large child psychiatry department during the COVID-19 crisis. J Child Adolesc Psychopharmacol 2020 Sep;30(7):404-413. [doi: 10.1089/cap.2020.0062] [Medline: 32639849]

38. Usman M, Fahy S. Coping with the COVID-19 crisis: An overview of service adaptation and challenges encountered by a rural Psychiatry of Later Life (POLL) team. Ir J Psychol Med 2021 Dec;38(4):288-292 [FREE Full text] [doi: 10.1017/ipm.2020.86] [Medline: $\underline{\text { 32611473] }}$

39. Viswanathan R, Myers MF, Fanous AH. Support groups and individual mental health care via video conferencing for frontline clinicians during the COVID-19 pandemic. Psychosomatics 2020;61(5):538-543 [FREE Full text] [doi:

10.1016/j.psym.2020.06.014] [Medline: $\underline{\text { 32660876] }}$

40. Wulfman R, Jourdain P, Ourahou O. Pendant le trauma: Une approche de la pathologie psychiatrique des patients atteints par le Covid-19 à travers la plateforme Covidom. Inf Psychiatr 2020;96(8):627-631. [doi: 10.1684/ipe.2020.2163]

41. Yellowlees P, Nakagawa K, Pakyurek M, Hanson A, Elder J, Kales HC. Rapid conversion of an outpatient psychiatric clinic to a 100\% virtual telepsychiatry clinic in response to COVID-19. Psychiatr Serv 2020 Jul 01;71(7):749-752. [doi: 10.1176/appi.ps.202000230] [Medline: 32460683]

42. Bocher R, Jansen C, Gayet P, Gorwood P, Laprévote V. Responsiveness and sustainability of psychiatric care in France during COVID-19 epidemic [Article in French]. Encephale 2020 Jun;46(3S):S81-S84 [FREE Full text] [doi: 10.1016/j.encep.2020.05.004] [Medline: 32471705]

43. Chherawala N, Gill S. Up-to-date review of psychotherapy via videoconference: Implications and recommendations for the RANZCP Psychotherapy Written Case during the COVID-19 pandemic. Australas Psychiatry 2020 Oct;28(5):517-520. [doi: 10.1177/1039856220939495] [Medline: 32689815]

44. Ćosić K, Popović S, Šarlija M, Kesedžić I. Impact of human disasters and COVID-19 pandemic on mental health: Potential of digital psychiatry. Psychiatr Danub 2020;32(1):25-31 [FREE Full text] [doi: 10.24869/psyd.2020.25] [Medline: 32303026]

45. Drogin EY. Forensic mental telehealth assessment (FMTA) in the context of COVID-19. Int J Law Psychiatry 2020;71:101595 [FREE Full text] [doi: 10.1016/j.ijlp.2020.101595] [Medline: 32768117]

46. Gautam M, Thakrar A, Akinyemi E, Mahr G. Current and future challenges in the delivery of mental healthcare during COVID-19. SN Compr Clin Med 2020 Jun 11:1-6 [FREE Full text] [doi: 10.1007/s42399-020-00348-3] [Medline: 32838140]

47. Grover S, Sarkar S, Gupta R. Data handling for e-mental health professionals. Indian J Psychol Med 2020 Oct;42(5 Suppl):85S-91S [FREE Full text] [doi: 10.1177/0253717620956732] [Medline: 33354071]

48. Hsu M, Ahern DK, Suzuki J. Digital phenotyping to enhance substance use treatment during the COVID-19 pandemic. JMIR Ment Health 2020 Oct 26;7(10):e21814 [FREE Full text] [doi: 10.2196/21814] [Medline: 33031044]

49. Melcher J, Hays R, Torous J. Digital phenotyping for mental health of college students: A clinical review. Evid Based Ment Health 2020 Nov;23(4):161-166. [doi: 10.1136/ebmental-2020-300180] [Medline: 32998937]

50. O'Brien M, McNicholas F. The use of telepsychiatry during COVID-19 and beyond. Ir J Psychol Med 2020 Dec;37(4):250-255 [FREE Full text] [doi: 10.1017/ipm.2020.54] [Medline: 32434596]

51. Roy A, Singh AK, Mishra S, Chinnadurai A, Mitra A, Bakshi O. Mental health implications of COVID-19 pandemic and its response in India. Int J Soc Psychiatry 2021 Aug;67(5):587-600 [FREE Full text] [doi: 10.1177/0020764020950769] [Medline: $\underline{\text { 32873106] }}$

52. Schroeder R. Adaptation or revolution: Telemental health and advanced practice psychiatric nursing during COVID-19. J Am Psychiatr Nurses Assoc 2020 Nov 09:1-8 [FREE Full text] [doi: 10.1177/1078390320970638] [Medline: 33164642]

53. Zhang E, LeQuesne E, Fichtel K, Ginsberg D, Frankle W. In-patient psychiatry management of COVID-19: Rates of asymptomatic infection and on-unit transmission. BJPsych Open 2020 Sep 01;6(5):e99 [FREE Full text] [doi: 10.1192/bjo.2020.86] [Medline: 32867874]

54. Bäuerle A, Graf J, Jansen C, Musche V, Schweda A, Hetkamp M, et al. E-mental health mindfulness-based and skills-based 'CoPE It' intervention to reduce psychological distress in times of COVID-19: Study protocol for a bicentre longitudinal study. BMJ Open 2020 Aug 13;10(8):e039646 [FREE Full text] [doi: 10.1136/bmjopen-2020-039646] [Medline: 32792455]

55. Dursun OB, Turan B, Pakyürek M, Tekin A. Integrating telepsychiatric services into the conventional systems for psychiatric support to health care workers and their children during COVID-19 pandemics: Results from a national experience. Telemed J E Health 2021 Mar;27(3):269-275. [doi: 10.1089/tmj.2020.0237] [Medline: 32821025]

56. El Hayek S, Cheaito M, Nofal M, Abdelrahman D, Adra A, Al Shamli S, et al. Geriatric mental health and COVID-19: An eye-opener to the situation of the Arab countries in the Middle East and North Africa region. Am J Geriatr Psychiatry 2020 Oct;28(10):1058-1069 [FRE Full text] [doi: 10.1016/j.jagp.2020.05.009] [Medline: 32425474] 
57. Feijt M, de Kort Y, Bongers I, Bierbooms J, Westerink J, IJsselsteijn W. Mental health care goes online: Practitioners' experiences of providing mental health care during the COVID-19 pandemic. Cyberpsychol Behav Soc Netw 2020 Dec;23(12):860-864. [doi: 10.1089/cyber.2020.0370] [Medline: 32815742]

58. Haxhihamza K, Arsova S, Bajraktarov S, Kalpak G, Stefanovski B, Novotni A, et al. Patient satisfaction with use of telemedicine in university clinic of psychiatry: Skopje, North Macedonia during COVID-19 pandemic. Telemed J E Health 2021 Apr;27(4):464-467. [doi: 10.1089/tmj.2020.0256] [Medline: 32809916]

59. Looi J, Allison S, Bastiampillai T, Pring W. Private practice metropolitan telepsychiatry in larger Australian states during the COVID-19 pandemic: An analysis of the first 2 months of new MBS telehealth item psychiatrist services. Australas Psychiatry 2020 Dec;28(6):644-648. [doi: 10.1177/1039856220961906] [Medline: 32997521]

60. Olwill C, Mc Nally D, Douglas L. Psychiatrist experience of remote consultations by telephone in an outpatient psychiatric department during the COVID-19 pandemic. Ir J Psychol Med 2021 Jun;38(2):132-139 [FREE Full text] [doi:

10.1017/ipm.2020.51] [Medline: $\underline{32438945]}$

61. Patel S, Gannon A, Cryan M, McDonnell N, Rafiq S, Adamis D, et al. Ordinary care in extraordinary times. Ir J Psychol Med 2020 Sep 11:1-5 [FREE Full text] [doi: 10.1017/ipm.2020.103] [Medline: 32912356]

62. Roncero C, García-Ullán L, de la Iglesia-Larrad JI, Martín C, Andrés P, Ojeda A, et al. The response of the mental health network of the Salamanca area to the COVID-19 pandemic: The role of the telemedicine. Psychiatry Res 2020 Sep;291:113252 [FREE Full text] [doi: 10.1016/j.psychres.2020.113252] [Medline: 32623263]

63. Conrad RC, Baum ML, Shah SB, Levy-Carrick NC, Biswas J, Schmelzer NA, et al. Duties toward patients with psychiatric illness. Hastings Cent Rep 2020 May;50(3):67-69 [FREE Full text] [doi: 10.1002/hast.1139] [Medline: $\underline{32596900]}$

64. Falala-Séchet C, Antoine L, Thiriez I. Owlie, un chatbot de soutien psychologique: Pourquoi, pour qui ? Inf Psychiatr 2020;96(8):659-666. [doi: 10.1684/ipe.2020.2168]

65. Genoud-Prachex T, Perrenoud M, Brioschi GA, Moser C, Bieler-Aeschlimann M, Rouaud O. Télé-neuropsychologie, patients âgés et Covid-19. Rev Neuropsychol 2020;12(2):178-180. [doi: 10.1684/nrp.2020.0564]

66. Goldin D, Maltseva T, Scaccianoce M, Brenes F. Cultural and practical implications for psychiatric telehealth services: A response to COVID-19. J Transcult Nurs 2021 Mar;32(2):186-190. [doi: 10.1177/1043659620973069] [Medline: 33150851]

67. Ibrahim FA, Pahuja E, Dinakaran D, Manjunatha N, Kumar CN, Math SB. The future of telepsychiatry in India. Indian J Psychol Med 2020 Oct;42(5 Suppl):112S-117S [FRE Full text] [doi: 10.1177/0253717620959255] [Medline: 33354056]

68. Jayarajan D, Sivakumar T, Torous JB, Thirthalli J. Telerehabilitation in psychiatry. Indian J Psychol Med 2020 Oct;42(5 Suppl):57S-62S [FREE Full text] [doi: 10.1177/0253717620963202] [Medline: 33354066]

69. Looi JC, Pring W. To tele- or not to telehealth? Ongoing COVID-19 challenges for private psychiatry in Australia. Australas Psychiatry 2020 Oct;28(5):511-513 [FREE Full text] [doi: 10.1177/1039856220950081] [Medline: 32847378]

70. Mohan A, Ambekar A. Telepsychiatry and addiction treatment. Indian J Psychol Med 2020 Oct;42(5 Suppl):52S-56S [FREE Full text] [doi: 10.1177/0253717620958169] [Medline: 33354065$]$

71. Cave J, Crews M. Rehabilitation during a pandemic: Psychiatrists as first responders? J Psychosoc Rehabil Ment Health 2020 Oct 22:1-2 [FREE Full text] [doi: 10.1007/s40737-020-00200-w] [Medline: 33110740]

72. Wasser T, Hauser L, Kapoor R. The management of COVID-19 in forensic psychiatric institutions. Psychiatr Serv 2020 Oct 01;71(10):1088-1090. [doi: 10.1176/appi.ps.202000584] [Medline: 32998660]

73. Gardner J, Plaven B, Yellowlees P, Shore J. Remote telepsychiatry workforce: A solution to psychiatry's workforce issues. Curr Psychiatry Rep 2020 Jan 27;22(2):8. [doi: 10.1007/s11920-020-1128-7] [Medline: 31989417]

74. Hilty DM, Sunderji N, Suo S, Chan S, McCarron RM. Telepsychiatry and other technologies for integrated care: Evidence base, best practice models and competencies. Int Rev Psychiatry 2018 Dec;30(6):292-309. [doi: 10.1080/09540261.2019.1571483] [Medline: 30821540]

75. Shore JH, Yellowlees P, Caudill R, Johnston B, Turvey C, Mishkind M, et al. Best practices in videoconferencing-based telemental health April 2018. Telemed J E Health 2018 Nov;24(11):827-832. [doi: 10.1089/tmj.2018.0237] [Medline: 30358514]

76. Yellowlees P, Richard Chan S, Burke Parish M. The hybrid doctor-patient relationship in the age of technology Telepsychiatry consultations and the use of virtual space. Int Rev Psychiatry 2015;27(6):476-489. [doi: 10.3109/09540261.2015.1082987] [Medline: 26493089]

77. Améliorer la Santé Mentale de la Population: Vers Une Stratégie sur la Santé Mentale Pour l'Union Européenne. Brussels, Belgium: European Commission; 2005 Oct 14. URL: https://ec.europa.eu/health/archive/ph determinants/life style/mental/ green paper/mental gp fr.pdf [accessed 2022-01-26]

78. Kocsis BJ, Yellowlees P. Telepsychotherapy and the therapeutic relationship: Principles, advantages, and case examples. Telemed J E Health 2018 May;24(5):329-334. [doi: 10.1089/tmj.2017.0088] [Medline: 28836902]

79. Zhang M, Smith HE. Digital tools to ameliorate psychological symptoms associated with COVID-19: Scoping review. J Med Internet Res 2020 Aug 21;22(8):e19706 [FREE Full text] [doi: 10.2196/19706] [Medline: 32721922]

80. Shore J. Best practices in tele-teaming: Managing virtual teams in the delivery of care in telepsychiatry. Curr Psychiatry Rep 2019 Jul 08;21(8):77. [doi: 10.1007/s11920-019-1052-x] [Medline: 31286277] 
81. Hilty DM, Rabinowitz T, McCarron RM, Katzelnick DJ, Chang T, Bauer AM, et al. An update on telepsychiatry and how it can leverage collaborative, stepped, and integrated services to primary care. Psychosomatics 2018;59(3):227-250. [doi: 10.1016/j.psym.2017.12.005] [Medline: 29544663]

\title{
Abbreviations \\ ARN: French National Research Agency \\ PHRC: French National Hospital Program for Clinical Research \\ PRISMA: Preferred Reporting Items for Systematic Reviews and Meta-Analyses
}

\author{
Edited by A Kushniruk; submitted 11.05.21; peer-reviewed by S Bonneton, P Yellowlees; comments to author 14.06.21; revised version \\ received 06.07.21; accepted 09.10.21; published 04.02.22 \\ Please cite as: \\ Kane H, Gourret Baumgart J, El-Hage W, Deloyer J, Maes C, Lebas MC, Marazziti D, Thome J, Fond-Harmant L, Denis F \\ Opportunities and Challenges for Professionals in Psychiatry and Mental Health Care Using Digital Technologies During the \\ COVID-19 Pandemic: Systematic Review \\ JMIR Hum Factors 2022;9(1):e30359 \\ URL: https://humanfactors.jmir.org/2022/1/e30359 \\ doi: $\underline{10.2196 / 30359}$ \\ PMID: 34736224
}

CHélène Kane, Jade Gourret Baumgart, Wissam El-Hage, Jocelyn Deloyer, Christine Maes, Marie-Clotilde Lebas, Donatella Marazziti, Johannes Thome, Laurence Fond-Harmant, Frédéric Denis. Originally published in JMIR Human Factors (https://humanfactors.jmir.org), 04.02.2022. This is an open-access article distributed under the terms of the Creative Commons Attribution License (https://creativecommons.org/licenses/by/4.0/), which permits unrestricted use, distribution, and reproduction in any medium, provided the original work, first published in JMIR Human Factors, is properly cited. The complete bibliographic information, a link to the original publication on https://humanfactors.jmir.org, as well as this copyright and license information must be included. 